\title{
A capability approach analysis of student perspectives of a medical consultation quality-improvement process
}

\author{
J M Louw, MB ChB, DTM\&H, MMed (FamMed), PhD (FamMed); T S Marcus, BSc (Econ), MSc, PhD; \\ J F M Hugo, MB ChB, MFamMed \\ Department of Family Medicine, School of Medicine, Faculty of Health Sciences, University of Pretoria, South Africa
}

Corresponding author: J M Louw (murray.louw@up.ac.za)

\begin{abstract}
Background. Research shows that person-centredness declines during medical education. This study examines the underlying assumptions and effects of clinical associate training interventions on person-centred practice.

Objectives. To understand student experiences of a medical consultation quality-improvement (QI) process in terms of a capability approach to learning and the effects of this process on their person-centredness.

Methods. In a randomised controlled trial students from 8 clinical learning centres (CLCs) participated in a qualitative, medical consultation QI process. Qualitative data (focus group discussions and reflective reports) were analysed using a capability approach to the learning framework.

Results. Learning was triggered by disruptions to students' abilities, knowledge, identity and relationships. Through facilitated review-read-reflectre/action scaffolded by feedback and practical assessment tools they learnt new person-centred consultation skills. The QI process functioned as a learning cycle in which students reviewed disruptions, identified areas for improvement and developed improvement plans. Through it, awareness of themselves developed more deeply, their relationships with peers and patients grew and they improved their knowledge and consultation skills. Conclusions. Students demonstrated learning through their understanding of the skills and competencies required for person-centred practice. The study found students to be at different points along the directed/self-directed learning continuum, with most of them developing abilities to learn independently, work in groups, give and receive feedback and apply learning across different contexts. Facilitation is particularly important, given the uneven development of the 'dimensions of a person' at an individual level. Lastly, the capability approach is useful as an analytical framework and as a way of 'doing learning'.
\end{abstract}

Afr J Health Professions Educ 2021;13(1):65-71. https://doi.org/10.7196/AJHPE.2021.v13i1.1224

Person-centred practice is an ethical imperative $e^{[1,2]}$ and an essential competency that has value for patients, clinicians and the health service. ${ }^{[3]}$ At its core is a holistic view of the patient as a person with a unique illness experience, as well as the creation of a therapeutic relationship between patient and clinician. ${ }^{[1]}$ Despite various interventions, research shows that person-centredness and its constituent elements decline during the training of medical students. ${ }^{[4-6]}$ To understand this phenomenon, it is necessary to examine the underlying assumptions and effects of training interventions on person-centred practice. This, in turn, requires an understanding of learning and the learner.

Marcus $^{[7]}$ refers to four dimensions of the learner as sources of human capacity and competency, i.e. physical and mental abilities, knowledge and beliefs, sense of self and identity and social relationships. When there is a disturbance to any, some or all of these dimensions, the person experiences uncertainty. This uncertainty becomes the trigger to several, preferably conscious, cognitive and metacognitive activities that lead to learning. These include reviewing the activities or events that triggered the disruption, finding new information and critically evaluating the new information against the disruption, while taking into account self and identity, relationships and competencies. All this is done to develop an appropriate plan of action. Through practice, learners improve or develop new competencies, and develop or deepen their understanding of themselves and others, thereby growing the ability to learn in a continuously iterative learning cycle. ${ }^{[8]}$ The capability approach (Fig. 1) ${ }^{[7,9,10]}$ enables learners to develop mastery and move towards self-directed learning over time. It needs to be made consciously visible, scaffolded and guided by mentors and teachers, for all individuals to learn how to use it. ${ }^{[9]}$

In this article, we use the capability approach to assess Bachelor of Clinical Medical Practice (BCMP) students' learning of person-centred consultation skills during a quality-improvement (QI) process on the medical consultation. Students with the BCMP degree are qualified to practise as clinical associates in South Africa (SA). ${ }^{[1]}$ They spend most of

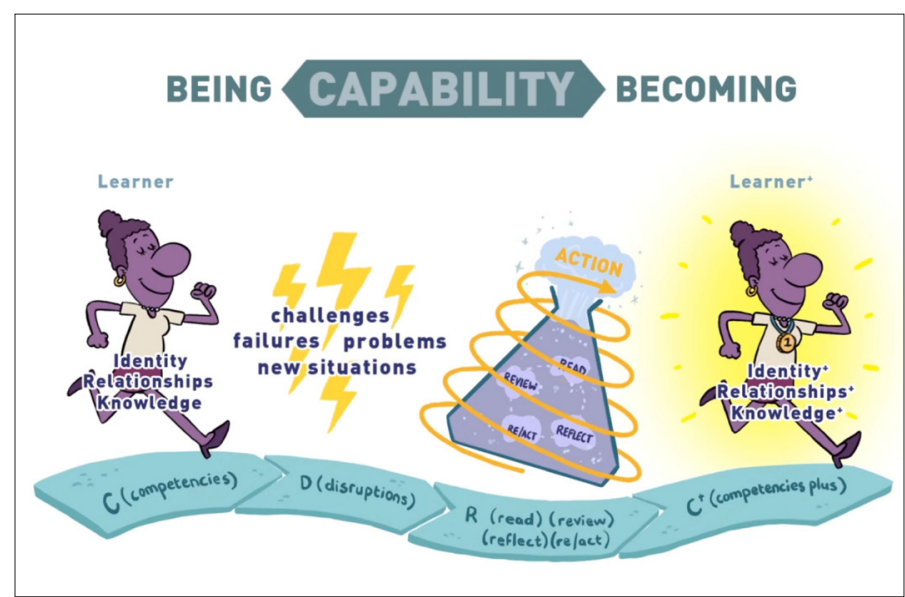

Fig. 1. The capability approach to learning. ${ }^{[7,9,10]}$ 
their 3 years of training doing service learning in a decentralised learning platform at clinical learning centres (CLCs). Typically, these comprise a district-level public hospital and its surrounding clinics. ${ }^{[12]}$ A local family physician provides oversight and leadership for student learning in each CLC, where students have daily contact with patients and conduct consultations under the supervision of qualified health professionals.

\section{Methods}

As part of a mixed-methods study, a randomised controlled trial of a QI intervention to learn person-centred practice was conducted with second- and third-year BCMP students. ${ }^{[13]}$ We report on the qualitative data from student reflective reports and focus group (FG) interviews with intervention group students. Students learning at 8 of 19 CLCs selected for the intervention by clustered randomisation were trained to implement the QI process as follows:

- Form a team of 2 - 4 fellow students in the same year group to work together to improve consultation skills.

- Read and reflect on 2 articles describing the medical consultation. ${ }^{[14,15]}$

- Study 4 consultation assessment tools: Kalamazoo Essential Elements Communication Checklist (adapted) (KEECC(A)), Consultation Peer Assessment Tool (adapted for students at the University of Pretoria), CARE Patient Feedback Measure and Patient Enablement Instrument.

- Measure current consultation practice by assessing each other's consultations with the tools provided. Consultations could be video recorded, audio recorded and/or observed in person. Give feedback to each other based on the tools, and reflect on patients' perceptions of their consultations as recorded in the tools. Do self-assessment using one or two of the tools.

- Plan and implement measures to improve their own consultations.

- Repeat the measurements of their consultation practice.

- Reflect on changes in their performance and submit a report on the QI process.

One CLC closed after randomisation, but before commencement of training for the intervention. The 3 affected students were moved individually to 3 other CLCs. Students at the remaining 10 CLCs served as controls.

Even though intervention group students were repeatedly encouraged to submit reports, only 9 reports were received. Data for this analysis (Fig. 2) were drawn from these 9 written reflection reports from 17 students in 4 CLCs and 10 focus group discussions (FGDs) that explored student experiences of the QI process on the medical consultation conducted between 19 October and 23 November 2015. All 62 students in the intervention group were invited (volunteer sampling) to participate in FGs when they were on campus for tests or examinations. Each FGD involved 2 - 12 participants, lasted 7 - 25 minutes and was conducted by the first author in English, audio recorded and transcribed. The $48 \mathrm{FG}$ participants included students from 7 of the 8 CLCs trained for the QI process. No student from CLC 8 volunteered to participate in an FGD, and no student participated in more than one FGD. In all FGDs, participants were asked: 'How are you progressing with the quality improvement on the medical consultation?', and 4 supplementary questions: 'How useful did you find the feedback that you were giving to one another?', 'How useful did you find the feedback from patients?', 'How useful did you find reflecting and thinking about your own consultation?' and 'How useful were the evaluation tools or rubrics?'
Data were interpreted using a capability approach to learning as a framework. For the purposes of this analysis, the physical and mental abilities of the learner were interpreted specifically in terms of consultation skills rather than as general abilities. Scaffolding for learning consultation skills included academic readings explaining the processes of the medical consultation, as well as assessment tools detailing the behaviours evaluated in a consultation. Guidance of learning included a QI process and advocating for a learning environment that enabled learners to engage meaningfully in the process. It was also facilitated by peer feedback among students to stimulate reflection on their performance as related to assessment tools. Feedback was deemed effective when it related to a specific learning context and was directed towards the attainment of specific goals. ${ }^{[16]}$

Data were analysed through repeated reading of the reports and transcribed texts, as well as repeated listening to the audio recordings to identify specific insights into learning the consultation skills required for person-centred practice and to relate these to the phases and elements of the capability approach to learning (Fig. 1). Quotations were coded and catalogued deductively in themes using the Atlas.ti (version 7.5) (Atlas.ti Scientific Software Development GmbH, Germany) computer program. Codes and themes were verified through discussions between the first and second authors, with involvement of the third author when there was no agreement.

\section{Ethical approval}

The study was granted ethical clearance by the Research Ethics Committees of the Mpumalanga Provincial Government and the Faculty of Health Sciences, University of Pretoria (ref. no. 128/2013).

\section{Results}

The average age of the 62 students in the intervention group was 23.3 years and $44 \%$ were female.

Describing their competencies prior to undertaking the QI process, students said that by their second year they had a better understanding

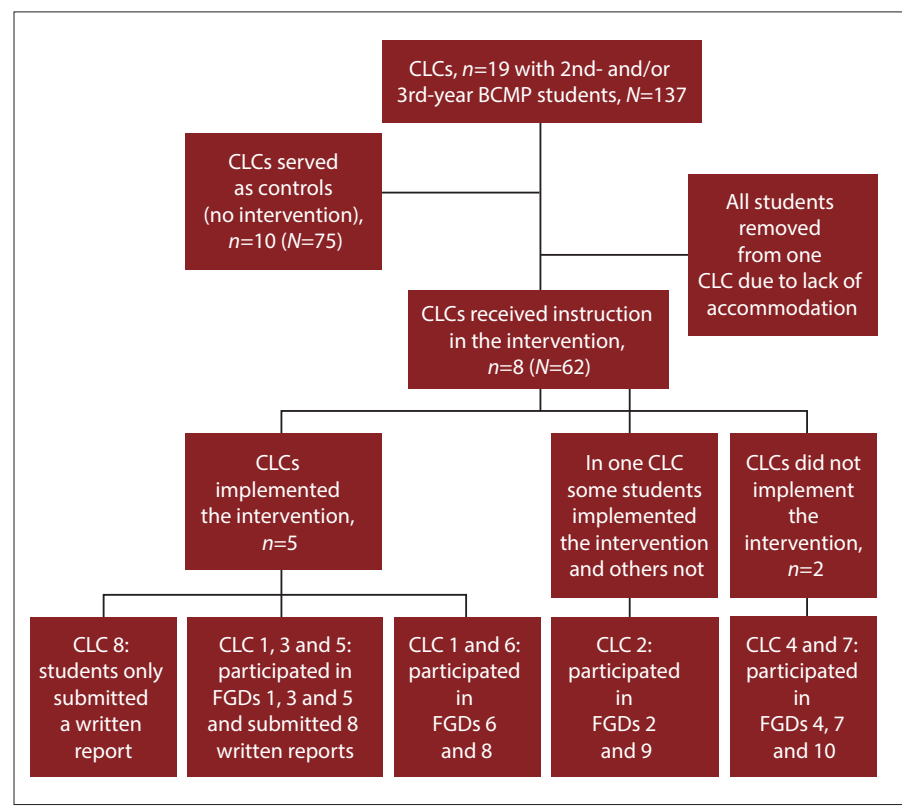

Fig. 2. Study sites, participants and data sources for the quality improvement process intervention. $(C L C s=$ clinical learning centres; $B C M P=$ Bachelor of Clinical Medical Practice; $F G D s=$ focus group discussions.) 
of person-centred practice, which prepared them for this QI process (Table 1: quote 1:25). They ascribed their skill in involving patients as equals in decision-making to previous training in preparation for an objective structured clinical examination (OSCE) (Table 1: quote 1:28). Students reported gaps in their knowledge of pharmacology (Table 2: quote 18:16), special investigations and communication skills (Table 1: quote 21:4).

In one instance, a student continued to externalise responsibility for learning (Table 3: quote 5:15).

Students experienced several disruptions in the QI process that triggered learning, including: being observed by peers (Table 3: quote 2:57; Table 4: quote 2:59) and/or recorded (Table 3: quote 2:16), while conducting a consultation, watching (Table 3: quotes 2:25 and 2:27) and listening (Table 1: quote 3:5) to recordings of themselves, not knowing enough (Table 2: quote 18:16; Table 4: quote 19:5) and feeling as though patients regarded them as incompetent (Table 3: quote 6:11; Table 4: quote 19:5). Some were also disrupted by technical and logistical barriers during implementation of the QI process and in 2 CLCs by administrative prohibition of recording videos of consultations together.

Students responded to the disruptions by reviewing their consultations through self-evaluation, using the consultation scoring tools (Table 1: quote 8:2), discussing with peers who observed them (Table 1: quote 3:14), listening to audio recordings (Table 1: quote 3:5) or watching video recordings (Table 3: quote 2:27).

Patient information needs triggered students to read up on pharmacology and investigative studies so that they could manage and explain the information to patients (Table 2: quotes 18:8 and 18:16; Table 4: quote 19:5).

Students became self-aware as they observed themselves in video and audio recordings (Table 1: quote 2:23; Table 3: quotes 2:26 and 2:27), with some responding that starting video recording themselves earlier in the course would have made them more comfortable (Table 1: quote 2:17). They reflected on their mannerisms and how they appear to patients (Table 3: quote 2:25). They also reflected on the way they interact in the consultation, becoming aware of not allowing patients to elaborate and of being unable to formulate open-ended questions (Table 3: quote 2:62). By watching their recordings, some gained an understanding of what it means to reflect (Table 3: quote 2:26), while others recognised that they were biased in their selfevaluations (Table 3: quote 1:33)

Through joint reflection on their consultation skills, students developed action plans to find solutions to the disruptions they experienced, such as reading about the subject, discussing issues with one another and others and practising (Table 3: quote 15:2; Table 2: quote 19:7; Table 1: quotes 20:8 and 21:9). For some, their insight into the value of learning with peers extended to planning co-operative learning to grow their all-round competencies beyond the QI process (Table 2: quote 19:7).

There were two different approaches to the disruption caused by administrative prohibition of video recording their consultations. Some students observed one another's consultations, used the reading material and gave one another feedback during consultations to improve their skills (Table 1: quote 6:22). Other students stopped the QI process to avoid confrontation with hospital management (Table 3: quote 7:6).

Specific feedback given by peers helped them learn physical examination and other consultation skills, such as not repeating questions and time management (Table 1: quotes 3:14, 5:34 and 20:4). They saw the value of diversity of experience and knowledge that came by way of peer learning, even suggesting that partners be rotated to get other opinions (Table 1: quote 21:9).
The presence of peers was less intimidating and they could implement what they learnt. Some felt facilitator feedback was too general or, at times, not given at all. Furthermore, the fear of making mistakes hampered their performance in formal assessments observed by an examiner (Table 4: quote 5:4).

Students did not find formal patient feedback helpful. They felt it did not contribute to their learning, because it was consistently positive and nonspecific.

Students reported that the readings and assessment tools to support their learning were helpful. They especially found that Hugo and Couper's ${ }^{[15]}$ juggling analogy helped them grasp key components of the consultation (Table 1: quote 8:12) and that the consultation assessment tools helped them identify areas for improvement during self-evaluation (Table 1: quote 8:2). Some found the English used in the Kalamazoo measuring tool difficult to follow and preferred the adapted consultation peer assessment tool.

In terms of new and strengthened person-centred practice, students expressed strong person-centred beliefs regarding the medical consultation. For example, they felt it was important to facilitate patients to tell their stories (Table 2: quote 2:54) and to focus more on the patient's ideas and feelings (Table 2: quote 2:49). They also believed that making a personal connection with the patient was therapeutic (Table 4: quote 6:26).

They reported learning valuable person-centred consultation skills, such as listening and building trust to discuss sensitive information (Table 1: quote 3:7); being fully focused on the patient to better explore their illness experience (Table 4: quote 6:5) and improve treatment adherence (Table 4: quote 6:7); eliciting patient expectations (Table 3: quote 6:8); adopting a holistic approach to find underlying causes of patients' worries and complaints (Table 1: quotes 6:9 and 3:6) and recognising the importance of negotiation to achieve compliance (Table 1: quote 6:6). Students considered consultation skills to be a foundation for clinical practice, suggesting that they be learnt prior to clinical skills in the earlier years of the programme.

\section{Discussion}

Students found the QI process a valuable opportunity to self-evaluate and identify practice areas needing improvement to gain the competencies expected of them as clinicians.

Our findings show that a self-directed QI process with evaluation tools, peer feedback and reflection on audio and video recordings led students to learning person-centred care. Disruptions triggered cognitive and metacognitive processes, which through scaffolding, enabled students to engage in a self-directed cycle of reading, reviewing, reflecting and acting or planning action, impacting on all their dimensions as learners. ${ }^{[9]}$

Watching video recordings of themselves conducting a consultation disrupted students' identity and sense of self. It triggered them to reflect on who they are, how they appear to others, and what they know or do not know. Self-awareness created through auto-critique is a recognised essential component for self-directed learning. ${ }^{[17,18]}$

As reported elsewhere, students found being recorded stressful, ${ }^{[17,19]}$ which may explain why many did not video record themselves. As proposed by these students and in other studies, ${ }^{[19]}$ this could be partly alleviated by introducing video recordings of consultations early in the course.

This study confirms the importance of motivation and self-efficacy for all learning, especially learning that centres on self-directed activities. ${ }^{[8]}$ The student groups who abandoned the QI process when they were unable or not permitted to video record their consultations failed to learn. Through their own agency, the groups who continued the QI process, either without 


\begin{tabular}{|c|c|c|c|}
\hline Quote reference & Student reference & Quote & Related to theme(s) \\
\hline $1: 25$ & $\begin{array}{l}\text { FG1, CLC1, } \\
\text { F, Yr2 }\end{array}$ & $\begin{array}{l}\text { 'I think we are better than during our first year } \ldots \text { on how to interview a patient and then make } \\
\text { that patient the centre of attention.' }\end{array}$ & Learner before \\
\hline $1: 28^{*}$ & $\begin{array}{l}\text { FG1, CLC1, } \\
\text { M, Yr2 }\end{array}$ & $\begin{array}{l}\text {... maybe if it was last semester it was going to be a problem, but for now because we even had } \\
\text { like an OSCE ... We know that you must ... not act like a boss whereby you must tell the patient } \\
\text { that this is what you must do ... It is between [you and] the patient, you discuss and you reach } \\
\text { like a certain agreement. So, it was not that bad because we were well trained in that aspect.' }\end{array}$ & Learner before \\
\hline $2: 17$ & $\begin{array}{l}\text { FG2, CLC2, } \\
\text { F, Yr3 }\end{array}$ & 'If we start(ed) this project in the beginning of the year by now ... you would have seen stars.' & Response \\
\hline $2: 23$ & $\begin{array}{l}\text { FG2, CLC2, } \\
\text { M, Yr3 }\end{array}$ & $\begin{array}{l}\text { 'But it is a good thing because after that you do reflect and you start thinking of okay, I should } \\
\text { have done this better, I should have done that and you learn actually, you learn a lot.' }\end{array}$ & Response \\
\hline 3:5 & $\begin{array}{l}\text { FG3, CLC3, } \\
\text { F, Yr3 }\end{array}$ & $\begin{array}{l}\text { '... we also got to pick up which questions we leave out in consultations and where we sometimes } \\
\text { tend to ask the same questions over and over again ... Recording helped us to pick up on that.' }\end{array}$ & $\begin{array}{l}\text { Disruption and } \\
\text { response }\end{array}$ \\
\hline $3: 7^{\dagger}$ & $\begin{array}{l}\text { FG3, CLC3, } \\
\text { M, Yr3 }\end{array}$ & $\begin{array}{l}\text { 'What I've learned is all about firstly, listening ... you create a rapport with the patient ... because } \\
\text { sometimes if you don't make them feel at ease they won't give you everything. Some of the things } \\
\text { they'll just keep them inside that they don't want to tell you. But if you make them feel at ease } \\
\text { they will tell you. At least they might manage to tell you some things. They might even tell you } \\
\text { things: "This one, even my family don't know'.' }\end{array}$ & Learner after \\
\hline $3: 14$ & $\begin{array}{l}\text { FG3, CLC3, } \\
\text { M, Yr3 }\end{array}$ & $\begin{array}{l}\text { 'I took a long consultation whereby I'm repeatedly asking the same question ... I go back ... and } \\
\text { then she [peer] told me ... don't spend more than fifteen minutes or ten minutes, but make } \\
\text { sure that you get everything that you need. But it doesn't mean that ... you just hurry up and } \\
\text { then you leave some important things out, but make sure that you gathered everything that you } \\
\text { needed so that you can go on with your working diagnosis.' }\end{array}$ & $\begin{array}{l}\text { Response and } \\
\text { facilitation }\end{array}$ \\
\hline $5: 34$ & $\begin{array}{l}\text { FG5, CLC3, } \\
\text { M, Yr3 }\end{array}$ & $\begin{array}{l}\text { 'I think the other thing is the feedback. You get a better feedback from your peers than [from] } \\
\text { facilitators. Some of them, they are in a rush. Sometimes you don't get feedback at all. They } \\
\text { [facilitators] say work on your skills of examination. Which one? Skills of examination? How? } \\
\text { In our peers we just get a clear feedback.' }\end{array}$ & Facilitation \\
\hline $6: 6^{*+}$ & $\begin{array}{l}\text { FG6, CLC6, } \\
\text { F, Yr3 }\end{array}$ & $\begin{array}{l}\text { 'Then on the management, you work together, you negotiate so that the patient can do } \\
\text { compliance. Using that facilitation and collaboration helped me a lot.' }\end{array}$ & Learner after \\
\hline $6: 9^{*}$ & $\begin{array}{l}\text { FG6, CLC6, } \\
\text { F, Yr3 }\end{array}$ & $\begin{array}{l}\text { 'You find that the patient may come to you, having a complaint that he is drunk, but the main } \\
\text { problem is depression ... So, as we dig further, as we approach the patient as a whole, we find } \\
\text { different diagnoses.' }\end{array}$ & Learner after \\
\hline $6: 22$ & $\begin{array}{l}\text { FG6, CLC6, } \\
\text { F, Yr3 }\end{array}$ & $\begin{array}{l}\text { 'As you're interviewing the patient, if maybe you forgot something to ask then he can help you } \\
\text { then. So that's how we give feedback.' }\end{array}$ & Facilitation \\
\hline $6: 36^{*}$ & $\begin{array}{l}\text { FG6, CLC6, } \\
\text { F, Yr3 }\end{array}$ & $\begin{array}{l}\text { 'So, it's better to understand that if you are not treating a human emotionally, even the adherence } \\
\text { is affected. The patient can't take the pills because the cause, the inner cause which is ... maybe } \\
\text { depression, is not sorted, your work would be in vain.' }\end{array}$ & Learner after \\
\hline $8: 2$ & $\begin{array}{l}\text { FG8, CLC1, } \\
\text { F, Yr3 }\end{array}$ & $\begin{array}{l}\text { 'When we did these questionnaires, like when we evaluated ourselves, it alerted us on where do } \\
\text { we lack on and then we have improved on that.' }\end{array}$ & $\begin{array}{l}\text { Response and } \\
\text { facilitation }\end{array}$ \\
\hline $8: 12$ & $\begin{array}{l}\text { FG8, CLC1, } \\
\text { M, Yr3 }\end{array}$ & $\begin{array}{l}\text { '... the thing that was most useful, it was reading the article, it tells about the important steps } \\
\text { that you need to outline in case of the consultation.' }\end{array}$ & Facilitation \\
\hline $20: 4$ & $\begin{array}{l}\text { QI report 6, } \\
\text { CLC3, } \\
2 \times \mathrm{M} \& \mathrm{~F}, \mathrm{Yr} 2\end{array}$ & $\begin{array}{l}\text { 'The examination still needs to be practiced, the exams of meningitis were not done well and } \\
\text { musculoskeletal examination was superficial not according to sequence and active range of } \\
\text { motion was not done, it was only passive.' }\end{array}$ & Facilitation \\
\hline $20: 8$ & $\begin{array}{l}\text { QI report 6, } \\
\text { CLC3, } \\
2 \times \mathrm{M} \& \mathrm{~F}, \mathrm{Yr} 2\end{array}$ & $\begin{array}{l}\text { '... take history on as many patients as possible to improve his consultation skills ... try to } \\
\text { examine lots of patients to be good.' }\end{array}$ & Response \\
\hline $21: 4$ & $\begin{array}{l}\text { QI report 7, } \\
\text { CLC3, } \\
2 \times \mathrm{M} \& \mathrm{~F}, \mathrm{Yr} 2\end{array}$ & $\begin{array}{l}\text { Weak points } \\
\text { Sharing information with a patient } \\
\text { Displaying sensitivity to the patient } \\
\text { Recognising patients' verbal clues } \\
\text { Supporting patient in coping with the current situation }\end{array}$ & Learner before \\
\hline $21: 9$ & $\begin{array}{l}\text { QI report } 7 \text {, } \\
\text { CLC3, } 2 \times \text { M \& } \\
\text { F, Yr2 }\end{array}$ & $\begin{array}{l}\text { Weak points } \\
\text { Do more consultations together and with a doctor where possible } \\
\text { Have a doctor to observe most of our consultations } \\
\text { Try and exchange partners just to get different opinions }\end{array}$ & $\begin{array}{l}\text { Response and } \\
\text { facilitation }\end{array}$ \\
\hline
\end{tabular}




\begin{tabular}{|c|c|c|c|}
\hline Quote reference & Student reference & Quote & Related to theme(s) \\
\hline $2: 49$ & $\begin{array}{l}\text { FG2, CLC2, } \\
\mathrm{M}, \mathrm{Yr} 3\end{array}$ & $\begin{array}{l}\text { 'Most time when you see a patient you just want to go straight to diagnosing what's wrong. } \\
\text { You don't hear what he feels, what he thinks, his ideas. You just wanna [go]: "Oh, he is } \\
\text { coughing: TB, pneumonia." You know, and go straight to treatment without focusing on the } \\
\text { patient's ideas: what he thinks, what he feels. Which is also just as important as the clinical } \\
\text { part.' }\end{array}$ & $\begin{array}{l}\text { Disruption and } \\
\text { response }\end{array}$ \\
\hline $2: 54$ & $\begin{array}{l}\text { FG2, CLC2, } \\
\mathrm{M}, \mathrm{Yr} 3\end{array}$ & $\begin{array}{l}\text { 'I was asking focused questions. If you have a headache, I'd be saying like: "Where is it? } \\
\text { Can you please point? Okay. No, I think it's this and this." Without allowing the patient to } \\
\text { say... to tell me more about the headache. }\end{array}$ & Disruption \\
\hline $18: 8$ & $\begin{array}{l}\text { QI report } 4 \\
\text { CLC1, } \\
2 \times M \text {, Yr2 }\end{array}$ & $\begin{array}{l}\text { 'It also helped us because we got to know more of pharmacology as we were explaining to } \\
\text { patient(s). }\end{array}$ & Response \\
\hline 18:16 & $\begin{array}{l}\text { QI report } 4 \\
\text { CLC1, } \\
2 \times \mathrm{M}, \text { Yr2 }\end{array}$ & $\begin{array}{l}\text { Weak points } \\
\text { 'Knowing the alternatives of medication, in case other medications are out of stock and } \\
\text { the correct doses as well. } \\
\text { Educating the patient on how to take medication and also the common adverse effects } \\
\text { associated with the medication prescribed. } \\
\text { Explaining to the patient why the medication is given and how it works. } \\
\text { Emphasising on patient adherence and compliance.' }\end{array}$ & $\begin{array}{l}\text { Learner before and } \\
\text { disruption }\end{array}$ \\
\hline 19:7 & $\begin{array}{l}\text { QI report 5, } \\
\text { CLC3, } \\
2 \times \text { M \& F, Yr2 }\end{array}$ & $\begin{array}{l}\text { '... planned meeting up every Friday as a group and come up with common conditions that } \\
\text { most patients present with to the hospital and discuss the right procedures, examinations } \\
\text { and tests to do in each and every condition.' }\end{array}$ & Response \\
\hline
\end{tabular}

video recording or by overcoming technical and logistical obstacles, were able to develop their critical thinking skills and gain valuable personcentred competencies.

As reported by Aper et al., ${ }^{[20]}$ conducting consultations with real patients both inspired and challenged students. Being regarded by them as incompetent, not only disrupted students' relationships with patients but also their sense of self. This has been described elsewhere as part of the process of identity formation, where individuals form their identity by imagining how they appear to and are judged by others. ${ }^{[21]}$ The QI process made students aware of how their own and patients' lack of confidence in their knowledge and abilities prevented them from inspiring trust in patients. For some, the awareness triggered by this disruption motivated self-development, driving them to re-establish and build themselves as competent healthcare student apprentices. For others, it triggered a defensive reaction that obstructed learning, as it cut to the core of their sense of self, leading them to express reluctance to share decision-making power with patients. This response points to the critical need for facilitation of learning to be an on-going process so that students develop the necessary competencies and skills to help them to retain their sense of self-worth and give them the confidence to collaborate with patients without appearing incompetent.

Through the QI process, students built and developed relationships with one another as peers. In this study, the principles of good feedback to promote changed practice were followed, i.e. that it be given face to face, be part of a coaching process (QI), contain specifics with examples, be based on observation, comparison (between peers) and a clear standard, as well as supporting positive change. ${ }^{[22]}$ The use of evaluation tools with clearly explained criteria to guide peer feedback ensured that what was said guided practice, even though it came from peers on the same level. Students demonstrated the ability to discern useful and unhelpful feedback. As with medical students, ${ }^{[17,23]}$ this study found that clinical associate students preferred peer feedback for its clarity and details and did not report any drawbacks. ${ }^{[24]}$ As in other research, the cognitive and social congruence between peers put students at ease being observed while conducting medical consultations. ${ }^{[25]}$ They felt that peers helped them focus, perform better and learn more than when they did consultations in the presence of a lecturer or examiner.

Although trained how to give feedback, the study found that student feedback was constrained by limitations in their knowledge of content and their relationships with one another. Generally, they gave feedback that related to their understanding of the knowledge and abilities required for the tasks and processes of the consultation, but did not address the issues of identity and relationships that these brought to light. This points to the important role of mentor and lecturer facilitation of learning to ensure that students are guided towards the best available knowledge and provided with deeper levels of feedback.

\section{Study limitations}

This study was conducted in a decentralised workplace-based training platform for clinical associate students and the findings may therefore not be generalisable to other teaching models.

Not all students submitted QI reports. Students from one of the intervention CLCs did not participate in the FGDs. They, however, submitted a joint report congruent with the rest of the data, suggesting that the results are an accurate reflection of their experiences with the QI process.

Despite repeated engagement with local supervisory structures, their support for the study was insufficient and contributed to variable implementation across CLCs.

FGDs 9 and 10 were of very short duration, largely because these involved only 2 or 3 students who did not implement the intervention. Even though 


\begin{tabular}{|c|c|c|c|}
\hline Quote reference & Student reference & Quote & Related to theme(s) \\
\hline $1: 33$ & $\begin{array}{l}\text { FG1, CLC1, } \\
\text { F, Yr2 }\end{array}$ & 'Usually you are biased to yourself so you can't say this was bad.' & Response \\
\hline 2:16 & $\begin{array}{l}\text { FG2, CLC2, } \\
\text { F, Yr3 }\end{array}$ & $\begin{array}{l}\text { 'But as soon as I, like, put the recorder there. I'm like, oh my gosh, I don't know } \\
\text { anything. So that was my problem.' }\end{array}$ & Disruption \\
\hline $2: 25$ & $\begin{array}{l}\text { FG2, CLC2, } \\
\text { M, Yr3 }\end{array}$ & $\begin{array}{l}\text { 'When you see yourself on a video, then you actually get a real idea of how you } \\
\ldots \text { present yourself to the patient ... If you have any funny mannerisms like "uh-huh } \\
\text {... uh-huh". }\end{array}$ & Disruption \\
\hline 2:26 & $\begin{array}{l}\text { FG2, CLC2, } \\
\text { F, Yr3 }\end{array}$ & $\begin{array}{l}\text { '... and that's when we all understood the part of reflection, and I must say I never } \\
\text { understood what reflection was until ... I watched myself and then I'm like, okay, now I } \\
\text { need to reflect.' }\end{array}$ & $\begin{array}{l}\text { Disruption } \\
\text { and response }\end{array}$ \\
\hline $2: 27^{*}$ & $\begin{array}{l}\text { FG2, CLC2, } \\
\text { F, Yr3 }\end{array}$ & $\begin{array}{l}\text { '... if you're watching the video you can see how you behave when talking to the patient } \\
\text { and the kind of questions that you are supposed to ask ... so it's a good reflection.' }\end{array}$ & Response \\
\hline 2:56 & $\begin{array}{l}\text { FG2, CLC2, } \\
\text { F, Yr3 }\end{array}$ & $\begin{array}{l}\text { Interviewer: 'What makes you learn the things you are now saying you are going to do } \\
\text { different?' Student: 'Watching ourselves ... }\end{array}$ & Disruption \\
\hline $2: 57^{\dagger}$ & $\begin{array}{l}\text { FG2, CLC2, } \\
\text { F, Yr3 }\end{array}$ & $\begin{array}{l}\text { '... and plus our colleague is in the room. Besides us watching ourselves ... someone else } \\
\text { is watching,' }\end{array}$ & Disruption \\
\hline $2: 62^{*}$ & $\begin{array}{l}\text { FG2, CLC2, } \\
\text { F, Yr3 }\end{array}$ & $\begin{array}{l}\text { 'One thing I learned about myself as an individual was that I tend to ask a lot of closed } \\
\text { questions. I don't give the patient an opportunity to elaborate on their presenting } \\
\text { complaint ... it's kind of hard for me to find open ended questions.' }\end{array}$ & $\begin{array}{l}\text { Learner before, } \\
\text { disruption and } \\
\text { response }\end{array}$ \\
\hline $5: 15$ & $\begin{array}{l}\text { FG5, CLC3, } \\
\text { F, Yr2 }\end{array}$ & $\begin{array}{l}\text { 'I was generally taught to go through full history ... So focused history, I don't know } \\
\text { what you are referring to ... How am I supposed to know that?' }\end{array}$ & Learner before \\
\hline $6: 11^{\dagger}$ & $\begin{array}{l}\text { FG6, CLC6, } \\
\text { F, Yr3 }\end{array}$ & $\begin{array}{l}\text { 'When you ask the patient to involve himself or herself, he feels like you don't know } \\
\text { what you are doing. "Why are you asking me this? You don't know what you are } \\
\text { supposed to do". }\end{array}$ & Disruption \\
\hline $6: 8^{+*}$ & $\begin{array}{l}\text { FG6, CLC6, } \\
\text { F, Yr3 }\end{array}$ & $\begin{array}{l}\text { 'In this thing, I've learnt that you should ask about the patient expectations. If you don't } \\
\text { meet the patient's expectations, then you become a bad clinician.' }\end{array}$ & Learner after \\
\hline $7: 6$ & $\begin{array}{l}\text { FG7, CLC7, } \\
\text { F, Yr3 }\end{array}$ & 'Someone suggested that I speak to him but I didn't.' & Response \\
\hline $15: 2^{*}$ & $\begin{array}{l}\text { QI report } 1 \text {, } \\
\text { CLC8, } \\
4 \times \mathrm{M}, \mathrm{Yr} 2\end{array}$ & $\begin{array}{l}\text { 'This study research was very helpful.... It gave us the opportunity to prove or rate } \\
\text { ourselves on how far we have developed when it comes to clinical practice, and where } \\
\text { we need to put more effort and practice more correctly in order to improve, so that we } \\
\text { can become quality and professional clinical associates.' }\end{array}$ & $\begin{array}{l}\text { Disruption, } \\
\text { response and } \\
\text { learner after }\end{array}$ \\
\hline
\end{tabular}

\begin{tabular}{|c|c|c|c|}
\hline Quote reference & Student reference & Quote & Related to theme (s) \\
\hline $2: 59$ & $\begin{array}{l}\text { FG2, CLC2, } \\
\text { F, Yr3 }\end{array}$ & $\begin{array}{l}\text { 'It's like even though we were comfortable with each other as soon as they are in a formal } \\
\text { setting, friendship goes away and it's like teacher-student relationship all of the sudden.' }\end{array}$ & Disruption \\
\hline $5: 4$ & $\begin{array}{l}\text { FG5, CLC3, } \\
\text { F, Yr2 }\end{array}$ & $\begin{array}{l}\text { 'And you become nervous when you are doing it with your facilitator "cause you're scared: } \\
\text { what if I do something wrong? But if it's your peer you are chilled, you just do everything } \\
\text { the way you learned ...". }\end{array}$ & Disruption \\
\hline $6: 5^{*+}$ & $\begin{array}{l}\text { FG6, CLC6, } \\
\text { F, Yr3 }\end{array}$ & $\begin{array}{l}\text { 'Ok, on my side, I learnt a lot. On the consultation: it's not about you as a clinician. It's about } \\
\text { the patient. Facilitating the patient, so that the patient can explore all the symptoms.' }\end{array}$ & Learner after \\
\hline $6: 7^{\dagger}$ & $\begin{array}{l}\text { FG6, CLC6, } \\
\text { F, Yr3 }\end{array}$ & $\begin{array}{l}\text { 'Then for a patient, it is easy to comply, as the patient sees that you are interested in him or } \\
\text { her and you understand better.' }\end{array}$ & Learner after \\
\hline $6: 26$ & $\begin{array}{l}\text { FG6, CLC6, } \\
\text { F, Yr3 }\end{array}$ & $\begin{array}{l}\text { 'And what we've learnt from this thing is that some of the patients they don't need medicine, } \\
\text { they need your touch, your smile, your time.' }\end{array}$ & Learner after \\
\hline 19:5 & $\begin{array}{l}\text { QI report 5, } \\
\text { CLC3, } \\
2 \times \mathrm{M} \& \mathrm{~F} \text {, Yr2 }\end{array}$ & $\begin{array}{l}\text { 'When it comes to selecting the right tests to perform ... and start going back to our books } \\
\text { to check what must we do next and we feel like that makes the patient to start doubting us.' }\end{array}$ & Disruption \\
\hline
\end{tabular}


FGDs 7 and 8 had 4 participants each, they were also of short duration. Participants in FGD 7 did not implement the intervention, while data generated in FGD 8 were congruent with the rest of the data. These limitations were mitigated by the number of FGDs and extent of data generated by the FGDs.

The researcher's position as BCMP programme co-ordinator may have prevented students discussing negative attitudes toward the course or patients. Even though students did not report personal negative attitudes toward patients, they did critique the consultation skills of other clinicians, as well as the timing of the QI intervention. However, the researcher's experience as a clinician allowed students to freely share their clinical experiences, which he could understand and empathise with. ${ }^{[26]}$

\section{Conclusion}

Students demonstrated the learning achieved in the QI process through their understanding of the skills and competencies required for personcentred practice.

Using a capability approach to understand the triggers and processes of learning person-centred care, the study revealed that students are at different points along the directed/self-directed learning continuum. While some had yet to internalise their responsibility for learning, most were developing their abilities to learn independently, to work in groups, to give and receive feedback and to apply what they have learnt across different contexts. Given the uneven development of the 'dimensions of a person' at an individual level, facilitation of learning is particularly important to help students translate disruptions into learning. Similarly, the cycle of reviewing, reading, reflecting and acting benefits all students when it is scaffolded through reading and evaluation instruments, as well as by creating deliberate opportunities for feedback. In addition to being a way of 'doing' learning, the article also demonstrates the usefulness of the capability approach as a framework to analyse if and how learning happens.

Based on the quality of learning, it is recommended that a QI process on the medical consultation with video recording be included in the undergraduate curriculum of clinicians. Areas for future research include the effects of different tools to guide self-evaluation and peer feedback, the role and place of video recording in the learning cycle, the best methods and processes to support the learning of person-centred practice, and an exploration of the development of students' 'review' competencies over time.

Declaration. The research for this study was done in partial fulfilment of the requirements for JML's $\mathrm{PhD}$ (Family medicine) degree at the University of Pretoria. Acknowledgements. Appreciation is expressed to the study participants, to Ms D Mhlari, Ms G Moodley, Mr K M Komana, Miss Z Sithole and Ms L I Mudau for transcribing the focus group recordings, and to Mrs $\mathrm{N}$ Smit for editing the manuscript. We thank Gerhard Cruywagen of Greenhouse Cartoons for designing Fig. 1.

Author contributions. JML: study conceptualisation, design, data collection and analysis; JML, TSM: interpretation framework; JML, TSM and JFMH: discussion and critical review.

Funding. None.

Conflicts of interest. None.

1. Louw JM, Marcus TS, Hugo JFM. Patient- or person-centred practice in medicine? A review of concepts. Afr Prim Health Care Fam Med 2017;9(1):a1455. https://doi.org/10.4102/phcfm.v9i1.1455

2. Entwistle VA, Watt IS. Treating patients as persons: A capabilities approach to support delivery of personcentered care. Am J Bioeth 2013;13(8):29-39. https://doi.org/10.1080/15265161.2013.802060

3. Olsson LE, Jacobsson UE, Swedberg K, Ekman I. Efficacy of person-centred care as an intervention in controlled Olsson LE, Jacobsson UE, Swedberg K, Ekman I. Efficacy of person-centred care as an interventio
trials - a systematic review. J Clin Nurs 2013;22(3-4):456-465. https://doi.org/10.1111/jocn.12039

4. Hojat M, Vegare MJ, Maxwell $\mathrm{K}$, et al. The devil is in the third year: A longitudinal study of erosion of empathy in
. Hojat M, Vegare M], Maxwell K, et al. The devil is in the third year: A longitudinal study of erosion of
medical school. Acad Med 2009;84(9):1182-1191. https://doi.org/10.1097/acm.0b013e3181b17e55

5. Bombeke K, van Roosbroeck S, de Winter B, et al. Medical students trained in communication skills show a decline in patient-centred attitudes: An observational study comparing two cohorts during clinical clerkships. Patient Educ Couns 2011;84(3):310-318. https://doi.org/10.1016/j.pec.2011.03.007

6. Archer E, van Heerden BB. Undergraduate medical students' attitudes towards patient-centredness: A longitudinal study. MedEdPublish 2017;6(3):47. https://doi.org/10.15694/mep.2017.000161

7. Marcus TS. COPC: A Practical Guide. 1st ed. Pretoria: Minuteman Press, 2018.

8. Sandars J, Cleary TJ. Self-regulation theory: Applications to medical education: AMEE Guide No. 58. Med Teach 2011;33(11):875-886. https://doi.org/10.3109/0142159x.2011.595434

2011;33(11):875-886. https://doi.org/10.3109/0142159x.2011.595434, Hugo J, Marcus T. Community-orientated primary care: Where there is a doctor. In: Mash
Family Medicine. 4th ed. Cape Town: Oxford University Press Southern Africa, 2017:334-359.

10. Marcus TS, Cruywagen G, Hugo JFM. 2017. A capability approach to learning. 2017. https://www.youtube.com/ watch? $\mathrm{v}=$ uwpr5OAUoVQ\&feature $=$ youtu.be

11. Bac M, Hamm J, van Bodegraven P, Pater B, Louw JM. A new health care profession in rural district hospitals: case study of the introduction of clinical associates in Shongwe Hospital. S Afr Fam Pract 2017;1(1):1-4. https:// doi.org/10.4102/safp.v59i1.4654

12. Moodley SV, Wolvaardt JE, Louw M, Hugo JFM. Practice intentions of clinical associate students at the University of Pretoria, South Africa. Rural Remote Health 2014;14:2381.

13. Louw JM, Hugo JFM. Learning person-centred consultation skills in clinical medicine: A randomised controlled Louw JM, Hugo JFM. Learning person-centred consultation skills in clinical medicine:
case study. S Afr Fam Pract 2020;62(1):a5109. https://doi.org/10.4102/safp.v62i1.5109

14. Fehrsen GS, Henbest RJ. In search of excellence. Expanding the patient-centred clinical method: A three-stage assessment. Fam Pract 1993;10(1):49-54. https://doi.org/10.1093/fampra/10.1.49

15. Hugo J, Couper I. The consultation: A juggler's art. Educ Primary Care 2005;16(5):597-604

16. Hattie J, Timperley H. The power of feedback. Rev Educ Res 2007;77(1):81-112.

17. Paul S, Dawson KP, Lanphear JH, Cheema MY. Video recording feedback: A feasible and effective approach to teaching history-taking and physical examination skills in undergraduate paediatric medicine. Med Educ 1998;32(3):332-336. https://doi.org/10.1046/j.1365-2923.1998.00197.x

18. Benbassat J, Baumal R. Enhancing self-awareness in medical students: An overview of teaching approaches. Acad Med 2005;80(2):156-161. https://doi.org/10.1097/00001888-200502000-00010

19. Ozcakar N, Mevsim V, Guldal D, et al. Is the use of videotape recording superior to verbal feedback alone in the 9. Ozcakar N, Mevsim V, Guldal D, et al. Is the use of videotape recording superior to verbal feedback alone
teaching of clinical skills? BMC Public Health 2009;9(474):5-9. https://doi.org/10.1186/1471-2458-9-474

20. Aper L, Veldhuijzen W, Dornan T, et al. 'Should I prioritise medical problem solving or attentive listening??: The dilemmas and challenges that medical students experience when learning to conduct consultations. Patient Educ Couns 2015;98(1):77-84. https://doi.org/10.1016/j.pec.2014.09.016

21. Cooley CH. Human Nature and the Social Order. New York: Charles Scribner's Sons, 1902

22. Archer J. Multisource feedback. Excel Med Educ 2012;1(2):28-30.

23. Al-Kadri HM, Al-Kadi MT, van der Vleuten CPM. Workplace-based assessment and students' approaches to learning: A qualitative inquiry. Med Teach 2013;35(Suppl 1):S31-S38. https://doi.org/10.3109/014215 9x.2013.765547

24. Cushing A, Abbott S, Lothian D, Hall A, Westwood OM. Peer feedback as an aid to learning. What do we want? Med Teach 2011;33(2):e105-e112.

25. Ten Cate O, Durning S. Dimensions and psychology of peer teaching in medical education. Med Teach 2007;29(6):546-552. https://doi.org/10.3109/0142159x.2011.542522

26. Berger R. Now I see it, now I don't: Researcher's position and reflexivity in qualitative research. Qual Res 2015;15(2):219-234. https://doi.org/10.1177\%2F1468794112468475

Accepted 18 November 2019 